\title{
KESETIAKAWANAN SOSIAL PADA PERKUMPULAN MASYARAKAT ADAT DAYAK HAMO DIRIK LEBANG NADO (HADI LEDO) DI KABUPATEN SINTANG
}

\author{
Mardawani, Linda Veronika \\ STKIP Persada Khatulistiwa Sintang, Pendidikan Pancasila dan Kewarganegaraan,Sintang \\ Email: mardawani113@yahoo.co.id , lindaveronika21081999@gmail.com
}

\begin{abstract}
This study was conducted in the district of Sintang, with title " social solidarity in the dayak tribe hamo dirik lebang nado ( hadi ledo ) in Sintang”. Based on the dynamics of Indonesian nation and state is farther away from the sublime values which is an original indonesian culture. This is evident from some phenomena as the waning a sense of family, solidarity, togetherness, fellow and tolerance. An association of hadi ledo as place of Dayak tribe to preserve their tribe especially the cultural values such asthe values of mutual aid and social solidarity. The Method was used to analyze data was a qualitative method form fenomenologis research study. The research found that : an association of hadi ledo has modern management complete as an organization. The members are around +200 members and developed by the customary called temenggung and the leaders of lebang nado association.An association of hadi ledo in general has been implementing activities in accordance with work programs of the organization. There are some activities organization which is containing the value of social solidarity that have been carried out regularly since 2015 such as: gawai behido (thanks giving), arisan (regular social gathering whose members contribute to and take turns at winning an aggregate sum of money), the meeting among the leaders, the meeting of member of incidental and unscheduled activities.
\end{abstract}

Key Words: Social Solidarity, Dayak Tribes.

ISSN: $2540-8038$ 


\begin{abstract}
Abstrak
Penelitian ini dilaksanakan di Kabupaten Sintang, dengan judul "Kesetiakawanan Sosial Pada Perkumpulan Masyarakat Adat Dayak Hamo Dirik Lebang Nado (HADI LEDO) Di Kabupaten Sintang". Dilatarbelakangi oleh dinamika kehidupan berbangsa dan bernegara Indonesia yang sudah semakin jauh dari nilai-nilai luhur yang merupakan kebudayaan asli bangsa Indonesia. Hal ini terindikasi dari bebarapa fenomena seperti semakin memudarnya rasa kekeluargaan, solidaritas, kebersamaan, dan toleransi sesama. Perkumpulan HADI LEDO menjadi wadah suku Dayak dalam melestarikan nilai-nilai budaya sukunya terutama gotong-royong dan kesetiakawanan sosial yang menjadi ciri khas. Metode yang digunakan untuk menganalisis data adalah metode kualitatif bentuk penelitian studi fenomenologis. Hasil penelitian ditemukan bahwa: Perkumpulan HADI LEDO saat ini memiliki kepengurusan lengkap sebagai sebuah organisasi modern. Dengan jumlah anggota \pm 200 anggota dan dibina pengurus adat yang disebut Temenggung dan tokoh masyarakat suku Lebang Nado. Perkumpulan HADI LEDO secara umum telah melaksanakan kegiatan sesuai dengan program kerja organisasi. Terdapat beberapa aktivitas organisasi HADI LEDO yang merupakan aktivitas yang mengandung nilai kesetiakawanan sosial yang dilaksanakan secara rutin sejak berdiri tahun 2015, diantaranya: gawai behido, arisan, rapat pengurus, pertemuan anggota dan kegiatan-kegiatan insidental yang tidak terjadwal.
\end{abstract}

Kata kunci : Kesetiakawanan Sosial, Masyarakat Adat Dayak.

ISSN: $2540-8038$ 


\section{A. Pendahuluan}

Sebagaimana kita ketahui bersama bahwa pada umumnya di era modern ini peran masyarakat adat sudah mulai tergeser oleh zaman. Arus globalisasi yang semakin tak terbendung diakui atau tidak mulai memainkan peranannya dalam pranata kehidupan sosial dan budaya masyarakat. Pada masyarakat modern sekarang ini, nilai-nilai dasar yang dulunya merupakan nilai luhur bangsa Indonesia tampak semakin memudar. Hal ini terindikasi dari bebarapa fenomena seperti semakin memudarnya rasa kekeluargaan, solidaritas, kebersamaan, dan toleransi sesama. Aktivitas-aktivitas yang bersifat tradisional di Indonesia yang merupakan pelestarian nilai-nilai luhur semakin menurun sebagai dampak masuknya arus globalisasi yang ditandai dengan kemajuan IPTEKS terutama yang berbasis teknologi informasi.

Secara khusus, provinsi Kalimantan Barat sebagai salah satu wilayah yang menjadi tempat hidup bagi masyarakat Dayak juga mengalami dinamika yang serupa. Kondisi masyarakat Dayak yang umumnya tinggal diperhuluan cenderung terpencil bahkan tertinggal dari segi pembangunan mau tidak mau menyebabkan mereka memiliki kecenderungan berpindah ke kota-kota, khususnya kota yang infrastrukturnya memadai. Sub suku Dayak Lebang Nado pada umumnya mendiami dua kecamatan yang ada di Kabupaten Sintang, yakni Kecamatan Kayan Hilir dan Kecamatan Dedai, sebagaian besar ada di Kecamatan Kayan Hilir. Kehidupan sub suku ini tergolong masih sangat jauh dari kemajuan, ini terlihat dari keberadaan infrastruktur jalan, signal hand phone dan fasilitas penerangan negara yang 99\% belum terjangkau. Suku ini tidak seperti suku Dayak lain, yang mendiami sekitar sungai (Sungai Kayan), yang bisa di jangkau dengan transportasi air, namun suku ini justru tinggal di daerah yang agak jauh dari aliran sungai besar. Sementara jalur darat masih terisolir. Hal ini semakin menyebabkan masyarakat semakin sulit mengakses informasi dan melaksanakan aktivitas ke perkotaan.

Pada saat ini, beberapa dari masyarakat suku Dayak Lebang Nado 
telah berpindah ke kota khususnya kota Kabupaten Sintang. Perpindahan ini dengan berbagai kompleksitas alasan seperti bekerja, mengikuti keluarga, ingin merubah nasib, sekolah dan lainlain. Masyarakat yang berpindah ke kota ada yang berhasil (khususnya mereka yang memiliki keahlian dan keterampilan), dan ada juga yang gagal dalam kehidupan ditengah arus perkotaan. Dalam perkembangannya Sub Suku Dayak Lebang Nado ini kemudian membentuk sebuah organisasi yang dinamakan Perkumpulan Hamo Dirik Lebang Nado yang disingkat HADI LEDO. Organisasi inilah yang menjadi wadah suku ini dalam melestarikan nilai-nilai budaya sukunya terutama gotongroyong dan kesetiakawanan sosial. Pembentukan organisasi ini sejalan dengan UUD 1945 khususnya pada “amandemen keempat UUD 1945 di dalam pasal 18 B ayat (2) digariskan bahwa Negara mengakui dan menghormati kesatuan-kesatuan masyarakat hukum adat beserta hak-hak tradisionalnya sepanjang masih hidup dan sesuai dengan perkembangan masyarakat dalam prinsip NKRI yang di atur dalam undang-undang, dan pada pasal 28 I ayat (3) menyatakan "Identitas budaya dan hak masyarakat tradisional dihormati selaras dengan perkembangan zaman dan peradaban".

Untuk mempermudah penyaluran partisipasi masyarakat dalam pembangunan, maka perlu adanya pemberdayaan terhadap nilainilai tradisional yang secara internal terpelihara (institusi-institusi lokal) dengan segenap atribut budayanya. Upaya ini dapat dilakukan dengan mengoptimalkan teknis pendekatan sosial budaya, dengan cara beradaptasi dan mengikutsertakan para tokoh adat ke dalam gerak langkah kebijaksanaan pemerintah dalam pelaksanaan pembangunan daerah.

Sebagai nilai dasar kesejahteraan sosial, kesetiakawanan sosial harus terus direvitalisasi sesuai dengan kondisi aktual bangsa dan diimplementasikan dalam wujud nyata dalam kehidupan kita. Kesetiakawanan sosial merupakan nilai yang bermakna bagi setiap bangsa. Jiwa dan semangat kesetiakawanan sosial dalam kehidupan bangsa dan masyarakat Indonesia pada hakekatnya telah ada sejak jaman nenek 
moyang kita jauh sebelum negara ini berdiri sebagai suatu bangsa yang merdeka yang kemudian dikenal sebagai bangsa Indonesia.

Jiwa dan semangat kesetiakawanan sosial tersebut dalam perjalanan kehidupan bangsa Indonesia telah teruji dalam berbagai peristiwa sejarah, dengan puncak manifestasinya terwujud dalam tindak dan sikap berdasarkan rasa kebersamaan dari seluruh rakyat bangsa Indonesia pada saat menghadapi ancaman dari penjajah yang membahayakan kelangsungan hidup bangsa.

Latar belakang di atas yang mendorong peneliti untuk melaksanakan penelitian terkait kesetiakawanan sosial pada perkumpulan masyarakat adat Dayak Hamo Dirik Lebang Nado di Kabupaten Sintang. Tujuan yang hendak dicapai dalam penelitian ini secara umum yakni untuk mengetahui bagaimanakah kesetiakawanan sosial pada perkumpulan masyarakat adat Dayak Hamo Dirik Lebang Nado di Kabupaten Sintang.

\section{B. Metode}

Metode yang digunakan dalam penelitian ini adalah metode kualitatif dengan bentuk studi fenomenologis. Metode ini dipilih berdasarkan permasalahan yang muncul dari adanya suatu fenomena yang terjadi. Subjek dalam penelitian ini adalah Perkumpulan Masyarakat Adat Dayak Lebang Nado yang tergabung dalam organisasi (perkumpulan) masyarakat adat Dayak Hamo Dirik Lebang Nado yang ada di Kabupaten Sintang Provinsi Kalimantan Barat. Objek pada penelitian ini adalah aktivitas Masyarakat Adat Dayak Lebang Nado yang tergabung dalam organisasi (perkumpulan) Hamo Dirik Lebang Nado yang ada di Kabupaten Sintang Provinsi Kalimantan Barat.

Penentuan subjek dan objek penelitian purposive sampling atau sampel bertujuan. Subjek dipilih menggunakan teknik Snowbal Sampling atau sampel jenuh, dimana jumlah subjek penelitian cenderung bertambah berdasarkan keperluan. Kriteria penentuan subjek penelitian diantaranya: suku Dayak Asli Lebang Nado atau keturunan yang tergabung 
dalam organisasi HADI LEDO (terdaftar baik sebagai pengurus maupun anggota) serta aktif dalam berbagai kegiatan yang diadakan organisasi.

Informan dalam penelitian ini adalah Tetua Adat Dayak Lebang Nado (Temenggung); Ketua dan pengurus Perkumpulan HADI LEDO Kabupaten Sintang; dan Anggota Aktif Perkumpulan HADI LEDO. Instrumen penelitian ini terdiri dari panduan wawancara, panduan observasi dan dokumentasi terkait aktivitas Masyarakat Adat Dayak Lebang Nado yang tergabung dalam organisasi / perkumpulan Hamo Dirik Lebang Nado yang ada di Kabupaten Sintang Provinsi Kalimantan Barat.

Setelah selesai proses pengumpulan data, diperoleh sejumlah data kualitatif. Analisis dan pengolahan data berpedoman pada data yang terkumpul dan pertanyaan penelitian. Data kualitatif dari penelitian ini yaitu hasil pengamatan dan wawancara yang dilakukan pada Masyarakat Adat Dayak Lebang Nado yang tergabung dalam organisasi (perkumpulan) masyarakat adat Dayak Hamo Dirik Lebang Nado yang ada di Kabupaten Sintang Provinsi Kalimantan Barat, data yang terkumpul dianalisis secara deskriptif.

Pada tahapan analisis data, penelitian kualitatif bersifat induktif, bahwa semua simpulan dibentuk dari semua informan yang diperoleh dari lapangan. Proses analisis ini dilakukan bersamaan sejak awal dengan proses pengumpulan data dengan melakukan beragam teknik refleksi bagi pendalaman dan pemantapan data. Setiap data yang diperoleh akan selalu dikomparasikan, setiap unit atau kelompoknya untuk melihat keterkaitan sesuia dengan tujuan penelitian. Selain itu bagi pemantapan dan pendalaman data proses yang dilakukan dalam bentuk siklus sebagai usaha verifikasi.

Teknik analisis data yang digunakan adalah teknik analisis data deskriptif kualitatif memanfaatkan persentase hanya merupakan langkah awal dari proses analisis data (Arikunto, 2000: 352). Dalam proses selanjutnya analisis data kualitatif terdiri dari empat alur kegiatan yang terjadi secara bersamaan, yaitu catatan lapangan, pengumpulan informasi, penyajian informasi, dan penarikan kesimpulan 
(Miles dan Huberman, 1992: 16-21). Proses analisis data dilakukan secara simultan yang mencakup klarifikasi, interpretasi dan analisis data. Analisis data dilakukan secara deskriptif (descriptive analysis). Hasil analisis data kemudian disajikan dalam bentuk laporan hasil penelitian (kesimpulan).

\section{Pembahasan Dan Hasil}

1. Pembahasan

a. Pengurus dan Keanggotaan pada Perkumpulan Masyarakat Adat Hamo Dirik Lebang Nado di Kabupaten Sintang.

Sebagai mana kita ketahui bahwa "masyarakat adat merupakan keturunan orang-orang yang pertama kali mendiami suatu wilayah ketika belum ada orang lain di wilayah tersebut sebelumnya (Bamba, 2006:6). Dalam hal ini terkandung juga pengertian bahwa nenek moyang masyarakat adat tersebut bisa jadi juga merupakan pendatang dari berbagai wilayah, namun merekalah yang pertama menempati wilayah tersebut. Komunitas-komunitas masyarakat asal atau pertama inilah yang kemudian dikenal dengan masarakat adat. Mereka hidup secara mandiri dan indenpenden di wilayah adat mereka masing-masing dengan sistem ekonomi, sosial, budaya yang tersendiri pula termasuk masalahmasalah yang menyangkut keberadaan dan status hukum masyarakat adat. Status hukum serta pengakuan hukum terhadap masyarakat hukum adat itu sendiri meliputi 3 unsur yakni : 1). Pengakuan terhadap keberadaan atau eksistensi; 2). Pengakuan terhadap hakhak atas sumberdaya alam atau agraria; dan 3). Pengakuan terhadap lembaga adat.

Di zaman modern masyarakat adat sudah tidak selalu identik berdiam di wilayah tertentu seperti pengertian diatas, masyarakat adat bisa saja berada di daerah lain seperti di wilayah dimana mereka tinggal dan menetap saat ini. Sebagaiamana yang ditemukan dari hasil penelitian dilapangan bahwa Perkumpulan Hamo Dirik Lebang Nado telah berdiri sejak tahun 2015, lewat Akta Notaris No. 21, Tanggal 21 Oktober 2015, beralamat Jl. Kelam Akcaya I, Gg. Gaeda. Perkumpulan ini berada bukan di wilayah asal mereka tetapi berada didaerah perkotaan (Kabupaten) Sintang. Saat ini memiliki 
kepengurusan inti terdiri dari seorang ketua, seorang wakil, seorang sekretaris dan seorang bendahara. Dengan jumlah anggota perkumpulan HADI LEDO yang ada di Kabupaten Sintang sejumlah \pm 200 anggota yang dibina dan diawasi oleh pengurus adat yang disebut Temenggung dan tokoh masyarakat suku Lebang Nado.

Sebagai sebuah organisasi, Perkumpulan HADI LEDO telah memenuhi syarat sebagai sebuah organisasi yang sah dimata hukum. Selain tercatat pada Akta Notaris, perkumpulan ini juga telah memiliki visi-misi dan AD/ART. Visi "terwujudnya masyarakat Lebang Nado yang bersatu, mandiri, aspiratif, indipenden". Sedangkan Misi: (1) Mencari dan menggali nilai-nilai budaya dan adat istiadat dalam komunitas suku Lebang Nado; (2). Membangun rasa kekeluargaan demi terciptanya keharmonisan antar sesama suku Lebang Nado; (3). Membentuk kelompok-kelompok di tiap kampung dengan prinsip kesetaraan dan transparansi untuk mewujudkan sistem yang terintegrasi; (4) Memperkuat jarinngan dengan menciptakan basis- basis pengkaderan demi keberlangsungan dan transformasi nilai; (5). Menyebarkan dan mempublikasikan nilai-nilai budaya dan adat istiadat suku Lebang Nado sebagai perekat dalam kerjasama antar komunitas; dan (5). Membangun sistem ekonomi dan memperkuat basis yang mandiri di dalam komunitas suku Lebang Nado.

Keberadaan Perkumpulan HADI LEDO merupakan hak masyarakat adat yang dijamin kehadirannya. Keberadaan komunitas masyarakat adat itu sendiri diatur dalam Deklarasi PBB tentang Hak-hak Masyarakat Adat Pasal 9 yang isinya : Masyarakat adat dan anggota indvidunya mempunyai hak untuk menjadi bagian dari suatu komunitas atau bangssa masyarakat, sesuai dengan tradisi-tradisi dan kebiasaan-kebiasaan dari komunitas atau bangsa masyarakat adat tersebut. Tidak ada diskriminasi apapun yang boleh timbul akibat dari pelakasanaan hak tersebut.

Menurut Kongres AMAN tahun 1999 Masyarakat Hukum Adat adalah komunitas-komunitas yang hidup berdasarkan asal usul leluhur secara turun temurun diatas suatu wilayah adat, yang memiliki kedaulatan atas tanah 
dan kekayaan alam, kehidupan sosial budaya yang diatur oleh hukum adat dan lembaga adat yang mengelolah keberlangsungan kehidupan masyarakat.

Dalam Rikrdo. S (2006: 96), untuk bisa mendapatkan hak-haknya masyarakat hukum adat tersebut harus memenuhi beberapa unsur :

1. Masyarakat masih dalam bentuk peguyuban(rechtsgemeenschap);

2. Adanya wilayah hukum adat yang jelas;

3. Adanya kelembagaan dalam bntuk perangkat penguasa adatnya;

4. Adanya pranata dan perangkat hukum, khususnya peradilan adat, yang masih ditaati; dan

5. Masih mengadakan pemungutan hasil hutan diwilayah hutan sekitarya untuk pemenuhan kebutuhan hidup sehari-hari.

Dari kelima unsur sebagaimana yang disebutkan diatas, masyarakat adat Lebang Nado yang ada di perkumpulan HADI LEDO masih memenuhi empat unsur dari kelima unsur tersebut dari point 1 sampai point 4 , sedangkan point 5 sudah tidak terpenuhi, hal ini dikarenakan mobilitas dan modernisasi yang ada diperkotaan bahwa ada pergeseran mata pencaharian jika di daerah asal mereka masih memiliki hasil hutan maka di kota mereka sudah tidak lagi memiliki kawasan hutan adat.

Disamping itu, pengakuan negara terhadap masyarakat hukum adat di Indonesia tertuang dalam UndangUndang Dasar 1945 Pasal 28 B ayat 2 yang berbunyi: Negara mengakui dan menghormati kesatuan masyarakat hukum adat beserta hak-hak tradisionalnya sepanjang masih hidup dan sesuai dengan perkembangan masyarakat serta terdapat juga dalam Pasal Pasal 28 I ayat 3 yang isinya: Identitas budaya dan hak masyarakat tradisional dihormati selaras dengan perkembangan zaman dan peradaban. Berdasarkan isi Pasal-pasal tersebut diatas dapat dikaji bahwa pengakuan negara terhadap hukum adat serta masyarakat hukum adat di Indonesia sudah diatur dalam peraturan perundang-undangan Indonesia. Istilah masyarakat adat mulai disosialisasikan di Indonesia di tahun 1993 setelah sekelompok orang yang menamakan dirinya Jaringan Pembelaan Hak-hak Masyarakat Adat (JAPHAMA) yang 
terdiri dari tokoh-tokoh adat, akademisi dan aktivis ornop menyepakati penggunaan istilah tersebut sebagai suatu istilah umum pengganti sebutan yang sangat beragam.

\section{Eksistensi}

perkumpulan

masyarakat adat HADI LEDO tidak terlepas dari peran ketemenggungan sebagai ketua suku Dayak Lebang Nado, dari temuan penelitian pada perkumpulan HADI LEDO juga peran tetua adat yang disebutkan Temenggung adat sebagai pembina yang berfungsi mengawasi dan memonitoring kegiatan organisasi. Fungsi ini juga dilaksanakan oleh tokoh masyarakat adat. Pada komunitas suku Dayak dari zaman dahulu hingga saat ini tidak terlepas dari peranan tetua atau dewan adat suku. Hal ini sejalan dengan yang dikemukan oleh Kifli (2007: 121), pada berbagai sub suku Dayak, meskipun sebutan bagi tetua atau tokoh adatnya berbeda-beda, namun memiliki peran yang sama yaitu sebagai panutan yang diikuti oleh komunitasnya". Tokoh adat merupakan pemimpin dalam komunitasnya dan memiliki otoritas dalam berbagai bidang sekaligus. Ketua adat tersebut sekaligus menandai bahwa terdapatnya organisasi kemasyarakatan pada masing-masing suku. Peran ketua adat sebagai pemimpin yang menjadi wadah komunikasi baik intern maupun hubungan keluar.

Di sisi lain, ditemuan juga bahwa masih ada sebagian dari sub suku tersebut yang belum tergabung sebagai anggota perkumpulan HADI LEDO, hal tersebut dikarenakan oleh beberapa alasan antara lain kesibukan, kurang informasi, dan masih belum memahami visi misi perkumpulan. Hal ini tentu menjadi masukan bagi perkumpulan HADI LEDO sebagai sebuah organisasi yang membina kesetiakawanan sosial kelompoknya. Sejauh ini memang telah diupayakan sosialisasi baik melalui media sosial maupun komunikasi secara langsung yang dilakukan oleh kepengurusan.

\section{b. Aktivitas Organisasi pada Masyarakat Adat Dayak Hamo Dirik Lebang Nado di Kabupaten Sintang.}

Perkumpulan masyarakat adat HADI LEDO merupakan kesatuan masyarakat dari Sub Suku Dayak yang ada di Kabupaten Sintang Provinsi Kalimantan Barat yakni Suku Dayak 
Lebang Nado. Seperti pada umumnya suku Dayak mayoritas tinggal di kawasan pedalaman dan perbatasan etnis Dayak sebagai terbesar yang menghuni pulau Kalimantan (Ibrahim, 2009: 2). Dayak atau Daya adalah sukusuku asli yang mendiami Pulau Kalimantan, Dayak berasal dari kata "Daya" yang artinya hulu, untuk menyebutkan masyarakat yang tinggal di pedalaman atau perhuluan Kalimantan umumnya dan Kalimantan Barat khususnya (walaupun kini banyak masyarakat dayak yang telah bermukim di kota atau provinsi), mempunyai kemiripan adat istiadat dan budaya dan masih memegang teguh tradisinya (Darmawanus, 2009). Dayak lebih tepat lagi adalah yang memiliki budaya teresterial (Pradita, 2013).

Perkumpulan masyarakat HADI LEDO adalah kelompok masyarakat yang mempertahankan eksistensi adatistiadatnya dalam kehidupan modern khususnya mempertahankan nilai-nilai luhur yakni prinsip kesetiakawanan sosial. Bagi HADI LEDO kesetiakawanan adalah keharusan. Kesetiakawanan muncul diilhami oleh prinsip gorong-royong, sebagaimana asal-usul suku ini yang dulunya hidup terpisah dari suku lain dan sering mengalami berbagai rintangan dalam hidupnya sehingga membentuk satu perasaan bahwa setiap rintangan dan tantangan harus dapat dihadapi bersama. Perkumpulan HADI LEDO merupakan wujud dari kesetiakawanan sosial suku Dayak Lebang Nado yang ada di kota Sintang.

Sebagai Suku yang mendiami salah satu daerah yang masih tertinggal, masyarakat suku Dayak Lebang Nado yang tergabung dalam sebuah organisasi adat yang di sebut HADI LEDO telah melaksanakan aktivitas keorganisasian layaknya organisasi pada umumnya. Memiliki kepengurusan, anggota dan AD/ART dan kegiatan sesuai dengan program kerja organisasi. Hidupnya sebuah organisasi tentu ditandai dengan berjalannya secara kontinu dan berkesinambungan kegiatan atau aktivitas sesuai visi misi organisasi. Sebagai sebuah organisasi perkumpulan HADI LEDO secara umum telah melaksanakan kegiatan sesuai dengan program kerja organisasi. Terdapat beberapa aktivitas organisasi HADI LEDO yang dilaksanakan secara rutin 
selama ini sejak berdiri tahun 2015, diantaranya: gawai behido, arisan, rapat pengurus, pertemuan anggota dan kegiatan-kegiatan insidental sperti sewaktu ada kematian, perkawinan, mandi anak, atau gotong royong pembangunan rumah, membantu yang mengalami musibah sakit, kebakaran, banjir dan sebagainya. Gawai behido merupakan wujud selamatan dan ucapan syukur yang dilakukan oleh suku Dayak Lebang Nado setiap tahun yang dilaksanakan pada bulan Juni-Juli setiap tahunnya. Makna dari gawai Behido adalah wujud rasa syukur dan beterima kasih atas rejeki dan keselamatan suku dayak Lebang Nado atas hasil kerja selama satu tahun berlalu. Gawai behido, sebenarnya berasal dari kata "BeHido" yang bermakna beselamat/slamatan ( yang mali jadi hido, yang jat jadi baik, yang salah jadi kenok $=$ yang tidak boleh menjadi boleh, yang jelek menjadi baik, yang salah menjadi benar). Pengertian ini mengandung doa dan harapan bahwa melalui perayaan gawai behido banyak kebaikan yang terjadi, memperbaiki segala yang salah, mentahirkan segala yang tidak baik dan membenarkan segala kekeliruan. Acara gawai ditandai dengan ritual adat manco tujuh dan adat denakng pati (adat/tradisi makan yang didahului tuan rumah, kemudian kepada tamu-tamunya dan dalam kebersamaan). Bentuk kegiatannya berupa makan bersama yang ditandai dengan adanya ritual ada. Selain itu juga dilaksanakan tradisi minum tuak pekejang (semacam minuman khas suku Dayak Lebang Nado) yang juga bermakna sebagai acara menyambut tamu dan penghormatan dalam perjamuan adat. Arisan merupakan wujud kegiatan yang bertujuan sosial untuk membantu anggota HADI LEDO yang memerlukan bantuan dana untuk berbagai keperluan. Rapat pengurus dan pertemuan anggota merupakan langkah koordinasi dan upaya penyehatan organisasi agar semua kegiatan dapat terlaksana sesuai dengan program kerja yang ada. Sedangkan kegiatan-kegiatan insidental dilaksanakan sebagai bentuk solidaritas dan kepekaan sosial sebagai wujud dari kesetiakawanan sosial pada suku Dayak Lebang Nado.

Memperhatikan kegiatan yang dilakukan oleh Perkumpulan HADI LEDO berdasarkan temuan penelitian 
tampak bahwa keberadaan komunitas adat sangat positif dalam membangun bangsa. Bagi suku Dayak Lebang Nado yang hidup diperantauan khususnya kota Sintang, kesuksesan bersama menjadi indikator dari kesuksesan dan eksistensi pribadi. Kegiatan-kegiatan yang dilakukan tidak hanya sebatas pelestarian nilai-nilai adat dan budaya, melainkan juga upaya mendukung pembangunan nasional mepererat persatuan dan kesatuan serta kerjasama dan gotong royong dalam komunitas masyarakat lokal yang berada diperkotaan. Keberadaan komunitas Adat Dayak, menurut konvensi ILO nomor 169 jo World Bank OD.4.20, untuk mengidentifikasii "indegeneous people" sebagai upaya merumuskan komunitas adat (Djuweng, 1997) dicirikan oleh berbagai hal yaitu: (1) memiliki keterikatan dengan wilayah asal-usulnya serta dengan sumber daya alam di wilayah tersebut, (2) adanya identifikasi diri yang kuat oleh masyarakat lain sebagai sebuah kelompok kebudayaan yang tersendiri / berbeda, (3) mempunyai bahasa asli sendiri yang sering berbeda dengan bahasa nasional yang berlaku, (4) masih berlakunya kelembagaan sosial dan politik adat, serta (5) sistem produksi masih berorientasi pada pemenuhan subsistensi.

\section{c. Kesetiakawanan Sosial pada Perkumpulan Masyarakat Adat Dayak Hamo Dirik Lebang Nado di Kabupaten Sintang.}

Kesetiakawanan Sosial atau rasa solidaritas sosial adalah merupakan potensi spritual, komitmen bersama sekaligus jati diri bangsa yang merupakan nilai-nilai luhur bangsa Indonesia yang tereplikasi dari sikap dan perilaku yang dilandasi oleh pengertian, kesadaran, keyakinan tanggung jawab dan partisipasi sosial sesuai dengan kemampuan dari masingmasing warga masyarakat dengan semangat kebersamaan, kerelaan untuk berkorban demi sesama, kegotongroyongan dalam kebersamaan dan kekeluargaan. Kesetiakawanan sosial (solidaritas sosial) adalah perasaan seseorang yang bersumber dari rasa cinta kepada kehidupan bersama sebagai mahluk sosial sehingga diwujudkan dengan amal nyata berupa pengorbanan dan kesediaan menjaga, 
membela, maupun melindungi terhadap kehidupan bersama. Konsep pembentukan organisasi atau perkumpulan HADI LEDO bersesuaian dengan pemaknaan kesetiakawanan sosial. Perkumpulan HADI LEDO dilandasi oleh komitmen bersama saling membantu, kegotongroyongan, kekeluargaan, kebersamaan dan solidaritas hidup masyarakat suku Dayak Lebang Nado yang ada di Kabupaten Sintang. Keinginan untuk saling membantu dan meringankan beban satu sama lain, serta kesadaran akan pentingnya pewarisan nilai-nilai dan tradisi luhur suku Lebang Nado menjadi alasan terbentuknya perkumpulan ini.

Menurut W.J.S. Poerwodarminta dalam KBBI, "kesetiaan" berasal dari kata dasar "setia" yang berarti "tetap dan teguh hati (dalam berkeluarga, persahabatan)". Sehingga, kesetiaan dapat diartikan sebagai sikap teguh pada pendirian dan taat pada janji, aturan, atau nilai-nilai yang sudah disepakati bersama. Kesetiakawanan yaitu perasaan seseorang yang bersumber dari rasa cinta kepada kehidupan bersama atau sesama teman sehingga diwujudkan dengan amal nyata berupa pengorbanan dan kesediaan menjaga, membela, membantu, maupun melindungi terhadap kehidupan bersama.

Dari pengertian kesetiakawanan tersebut kita bisa merasakan atau menilai rasa kemanusiaan seseorang. Rasa kesetiakawanan dapat dimaknai sebagai sikap : 1). kepentingan pribadi tetap diletakkan dalam kerangka kesadaran kewajiban sebagai makhluk sosial dalam kehidupan bermasyarakat, 2). kewajiban terhadap masyarakat dan bangsa dirasakan lebih besar dari kepentingan pribadinya.

Berikut adalah beberapa aktivitas pada organisasi HADI LEDO yang mengandung nilai-nilai kesetiakawanan sosial, antara lain: (1). Gawai Behido, upacara adat sebagai wujud ucapan terima kasih kepada sang pencipta atas hasil panen atau hasil pekerjaan dalam satu tahun; (2). Arisan HADI LEDO, yaitu arisan yang gunanya untuk mempererat tali persaudaraan bagi sub Suku Dayak yang ada diperantauan; (3). Berari-ari, sistem kerja balas-membalas membantu satu sama lain yang sifatnya sukarela tidak diperhitungkan berat atau 
ringannya pekerjaan; (4). Mintok Rimpuh, tradisi gotong royong yang dilaksanakan pada sub Suku Dayak Lebang Nado dalam menyelesaikan pekerjaan tertentu secara insidental yang berdasakan beberapa kriteria seperti diantaranya pada orang yang terkena musibah, anak yatim piatu, keluarga kurang mampu, warga pendatang yang belum mempunyai penghasilan tetap dan yang mengalami kesulitan lainnya.

\section{Simpulan}

Sebagai sebuah organisasi, Perkumpulan HADI LEDO telah memenuhi syarat sebagai sebuah organisasi yang sah dimata hukum. Selain tercatat pada Akta Notaris, perkumpulan ini juga telah memiliki visi-misi dan $\mathrm{AD} / \mathrm{ART}$ serta program kerja yang dijalankan.

Disamping itu, dari temuan penelitian pada perkumpulan HADI LEDO juga tidak terlepas dari peran tetua adat yang disebut Temenggung adat sebagai pembina yang berfungsi mengawasi dan memonitoring kegiatan organisasi. Di sisi lain, ditemuan juga bahwa masih ada sebagian dari sub suku tersebut yang belum tergabung sebagai anggota perkumpulan HADI LEDO, hal tersebut dikarenakan oleh beberapa alasan antara lain kesibukan, kurang informasi, dan masih belum memahami visi misi perkumpulan.

Hidupnya sebuah organisasi tentu ditandai dengan berjalannya secara kontinu dan berkesinambungan kegiatan atau aktivitas sosial. Sebagai sebuah organisasi perkumpulan HADI LEDO secara umum telah melaksanakan kegiatan sesuai dengan program kerja organisasi. Terdapat beberapa kegiatan organisasi HADI LEDO yang dilaksanakan secara rutin sejak berdiri tahun 2015, diantaranya: arisan, gawai behido, rapat pengurus, pertemuan anggota dan kegiatan-kegiatan insidental sperti waktu ada kematian, perkawinan, permandian anak, atau gotong royong pembuatan rumah, membantu yang mengalami musibah sakit, kebakaran banjir dan sebagainya.

Aktivitas pada organisasi HADI LEDO yang mengandung nilai-nilai kesetiakawanan sosial, antara lain: (1). Gawai Behido, upacara adat sebagai wujud ucapan terima kasih dan selamatan kepada sang pencipta atas 
hasil panen atau hasil pekerjaan dalam satu tahun; (2). Arisan HADI LEDO, yaitu arisan yang gunanya untuk mempererat tali persaudaraan bagi sub Suku Dayak yang ada diperantauan; (3). Berari-ari, sistem kerja balas-membalas membantu satu sama lain yang sifatnya sukarela tidak diperhitungkan berat atau ringannya pekerjaan; (4). Mintok Rimpuh, tradisi gotong royong yang dilaksanakan pada sub Suku Dayak Lebang Nado dalam menyelesaikan pekerjaan tertentu yang berdasakan beberapa kriteria seperti diantaranya pada orang yang terkena musibah, anak yatim piatu, keluarga kurang mampu, warga pendatang yang belum mempunyai penghasilan tetap dan yang mengalami kesulitan lainnya.

\section{Daftar Pustaka}

Darmawanus.

Online

Di

Http://Rdarmawanus.Blogspot.Co. Id/2009/12/Kondisi-Suku-DayakDi-Tengah-Arus.Html, 2009

Djuweng, S. (1997). Indigeneous Peoplesand Land Use Policy In Indonesia, A Dayak Show Case, IDRD Pontianak.

Institut Dayakologi \& Green Library. 2006. Dokumen Internasional Dan Nasional Tentang
Masyarakat

Adat.

Pontianak:Mitra Kasih.

Ibrahim, Ourida. (2009). Dayak Kalimantan Timur: Sebuah Catatatan Perjalanan.

Kalimantan Timur: PT. Gheananta Cahaya Abadi.

Kifli, Gontom C. 2007. Strategi Komunikasi Pembangunan Pertanian Pada Komunitas Dayak Di Kalimantan Barat. Jurnal Forum Penelitian Agro Ekonomi. Volume 25 No. 2, Desember 2007: 117-125.

Miles, Mattew B Dan Hubermen, Michael. 1992. Analisa Data Kualitatif: Buku Sumber Tentang Metode Baru, Terjemahan Tjetjep Rohendy (2007), Jakarta: UI Press.

Nawawi Hadari. 2007. Metode Penelitian Bidang Sosial, Yogyakarta; Gadjah Mada University Press.

Pradita, Marcellina Eka. 2013. Tato Sebagai Sebuah Media Komunikasi Non Verbal Suku Dayak Bahau. Ejournal Ilmu Komunikasi.Ejournal,Ilkom.FisipUnmul.Ac.Id

Soekanto, Soerjono. (2013). Hukum Adat Indonesia. Jakarta: Rajawali Press

Sulasman \& Gumilar, Setia. (2013). Teori-Teori Kebudayaan: Dari Teori Hingga Aplikasi. Bandung: Pustaka Setia. 